\title{
AKTIVITAS EKSTRAK DAUN RUMPUT BERMUDA (Cynodon dactylon L. Pers) TERHADAP PENYEMBUHAN LUKA BAKAR PADA KELINCI (Oyctolagus cuniculus)
}

\section{(ACTIVITY OF EXTRACT OF BERMUDA GRASS (Cynodon dactylon L. Pers) LEAF IN BURN TREATMENT ON RABBITS (Oyctolagus cuniculus))}

\author{
Nurlaila Ramadhani $^{10}$, Yusriadi ${ }^{1}$, Khildah Khaerati ${ }^{1}$ \\ ${ }^{1}$ Jurusan Farmasi Strata 1, FMIPA Universitas Tadulako, Palu - Sulawesi Tengah, 92118
}

\begin{abstract}
Abstrak: Penelitian ini bertujuan untuk mengetahui aktivitas ekstrak daun rumput bermuda (Cynodon dactylon L. Pers) terhadap penyembuhan luka bakar serta mengetahui konsentrasi yang efektif terhadap penyembuhan luka bakar. Hewan uji yang digunakan pada penelitian ini adalah kelinci jantan (Oryctolagus cuniculus) yang dibagi dalam 5 kelompok uji. Setiap kelinci dibuat luka bakar di bagian punggung dengan diameter $2 \mathrm{~cm}$, kelompok uji I diberi gel Bioplasenton (kontrol positif), kelompok II diberi basis Na CMC (kontrol negatif), kelompok uji III, IV, dan V diberi sediaan ekstrak daun rumput bermuda dengan konsentrasi masing-masing 1\%, 3\%, dan 5\%. Pengukuran luka bakar menggunakan alat jangka sorong dilakukan setiap hari selama 21 hari. Data yang diperoleh dianalisis menggunakan uji One way Anova dan dilanjutkan uji Post hoc Duncan. Hasil statistik menunjukkan bahwa ekstrak daun rumput bermuda memiliki aktivitas dalam penyembuhan luka bakar pada kelinci. Konsentrasi yang efektif adalah konsentrasi 5\%.
\end{abstract}

Kata kunci: ekstrak daun rumput bermuda (Cynodon dactylon L. Pers), luka bakar, kelinci

Abstract: This study aims to determine the activity of the extract of Bermuda grass (Cynodon dactylon L. Pers) in burn treatment and to identify the effective concentration in burn treatment. The testing animals employed were male rabbits (Oryctolagus cuniculus) divided into 5 testing groups. Each rabbit made burn on the back of $2 \mathrm{~cm}$ in diameter; the first group was administered Bioplacenton gel (positive control), group II was administered $\mathrm{Na} \mathrm{CMC}$ (negative control), group III, IV, and V were administered the extract of bermuda grass leaf of different concentration of $1 \%, 3 \%$, and $5 \%$ respectively. The measurement of the burn used Vernier Caliper every day for 21 days. The data obtained were analyzed using the One Way Anova test and followed by the Post hoc Duncan test. The statistical result shows that the extract of bermuda grass contribute to the burn treatment activity in rabbits. The effective concentration is of 5\%.

Keywords: burn, extract of bermuda grass (Cynodon dactylon L. Pers), rabbit

\section{PENDAHULUAN}

Luka merupakan bagian dari kehidupan suatu mahluk hidup. Luka dapat terjadi pada sistem kehidupan ditingkat manapun seperti pada sel, jaringan, organ ataupun organisme (Martin dan Alexander, 2017). Luka bakar adalah luka yang dapat ditimbulkan oleh panas (api, air panas, matahari, arus listrik), atau oleh zat-zat kimia (asam atau basa keras) (Jailani, 2005). Luka bakar merupakan respon kulit dan jaringan subkutan terhadap trauma suhu/termal. Luka bakar dengan ketebalan parsial merupakan luka bakar yang tidak merusak epitel kulit maupun hanya merusak sebagian dari epitel (Grace dkk., 2006).

Cynodon dactylon (Rumput bermuda) adalah rumput alami yang tersebar di seluruh dunia dan terutama adalah asli daerah beriklim hangat dan tropis. Tanaman ini kaya akan metabolit protein, karbohidrat, mineral, flavonoid, karotenoid, alkaloid, glikosida dan triterpenoid. Selanjutnya, rumput Cynodon dactylon ini sudah banyak digunakan secara tradisional sebagai Obat-obatan untuk mengobati berbagai penyakit seperti batuk, sakit kepala, diare, kram, epilepsi, sakit kepala, disentri, pendarahan, hipertensi, histeria, campak, sengatan gigitan, luka, gangguan urogenital batu, tumor, dan kutil (Kaliyaperumal, A, 2013).

Secara empiris daun rumput bermuda (Cynodon dactylon) memiliki penyebaran cukup luas di Desa Kaliburukata, Kec. Sindue, Kab. Donggala. Masyarakat kaliburukata sering menggunakan tumbuhan daun rumput bermuda (Cynodon dactylon) sebagai obat tradisional untuk menyembuhkan luka, seperti luka teriris pisau atau luka sayat oleh benda tajam dengan

• email korespondensi: nurlailaramadhani8@gmail.com 
cara menghaluskan daun rumput bermuda dengan cara dikunyah atau ditumbuk lalu ditempelkan pada permukaan luka yang terbuka. Tanaman ini juga dijadikan sebagai makanan pakan ternak.

Berdasarkan uraian di atas, maka dilakukan penelitian untuk mengetahui aktivitas ekstrak daun rumput bermuda (Cynodon dactylon) terhadap penyembuhan luka bakar pada kelinci (Oryctolagus cuniculus) jantan. Dimana pada penelitian ini menggunakan kelinci jantan yaitu diperlakukan selayaknya makhluk hidup yang diadaptasi terlebih dahulu sebelum digunakan.

\section{METODE PENELITIAN}

\section{Jenis dan Rancangan Penelitian}

Jenis penelitian ini adalah merupakan jenis penelitian eksperimen laboratorium dengan menggunakan kelinci putih jantan yang diinduksi dengan luka bakar untuk melihat pengaruh pemberian topikal ekstrak daun rumput bermuda terhadap penyembuhan luka bakar tersebut. Dengan menggunakan 5 kelompok perlakuan yaitu kontrol negatif, kontrol positif, dan kelompok perlakuan dengan variasi tiga konsentrasi ekstrak daun rumput bermuda yaitu $1 \%$, 3\%, dan $5 \%$. Selanjutnya data yang diperoleh berupa diameter luka kemudian dianalisis secara statistik dengan uji one-way anova yang dilanjutkan dengan uji post hoc duncan pada taraf kepercayaan $95 \%$.

\section{Tempat Penelitian}

Pembuatan ekstrak daun rumput bermuda Cynodon datylon di Laboratorium Farmakognosi-Fitokimia dan pemberian perlakuan dilakukan di Laboratorium Farmakologi-Biofarmasi Jurusan Farmasi, Fakultas Matematika dan Ilmu Pengetahuan Alam, Universitas Tadulako, Palu, Sulawesi tengah.

\section{Alat dan Bahan penelitian}

Alat-alat yang digunakan dalam penelitian ini yaitu, cawan porselen, gelas ukur (IWAKI PIREX $X^{\circledR}$ ), batang pengaduk, corong (IWAKI $\left.P I R E X^{\circledR}\right)$, wadah maserasi, wadah penguap, neraca analitik (PIONER $\left.{ }^{\circledR}\right)$, surgical blade, Vacuum Rotary Evaporator $\left(E Y E L A^{\circledR}\right)$, jangka sorong, kandang kelinci, timbangan hewan $\left(O H A U S^{\circledast}\right)$, penggaris, spidol, alat pencukur rambut, pot salep, sudip, aluminium foil, akuades, etanol 96\%, asam klorida pekat, asam asetat, pereaksi dragendroff, pereaksi mayer, pereaksi wagner, serbuk $\mathrm{Mg}, \mathrm{FeCl}_{3}, \mathrm{H}_{2} \mathrm{SO}_{4}$, $\mathrm{NaCl}, \mathrm{PEG}$, gliserin, $\mathrm{Na}-\mathrm{CMC}, \mathrm{NaCL}$ fisiologis, ketamin dan gel bioplasenton, pakan hewan uji (makanan kelinci).

\section{Prosedur kerja}

\section{Pembuatan Ekstrak Rumput Bermuda}

Pembuatan ekstrak dilakukan dengan cara maserasi menggunakan etanol 96\%. Dengan cara simplisia kering dimasukkan kedalam toples kemudian ditambahkan beberapa bagian pelarut etanol hingga dapat merendam seluruh simplisia, selanjutnya simplisa direndam selama 6 jam sambil sesekali diaduk, kemudian diamkan selama 3 x 24 jam. Setelah itu simplisia disaring dan kemudian dipekatkan dengan rotary evaporator pada suhu $70^{\circ} \mathrm{C}$ sampai didapatkan ekstrak kental.

\section{Pembuatan basis gel}

Menurut Mappa dkk (2013), prosedur pembuatan formula standar basis gel berdasarkan $\%$ b/b yaitu:

Tabel 1. Formula Standar Basis Gel

\begin{tabular}{ccc}
\hline No & Bahan & Komposisi $(\% \mathbf{b} / \mathbf{b})$ \\
\hline $\mathbf{1}$ & Na-CMC & $5 \%$ \\
\hline $\mathbf{2}$ & Gliserin & $10 \%$ \\
\hline $\mathbf{3}$ & Propilenglikol & $5 \%$ \\
\hline $\mathbf{4}$ & Akuades ad & 100 \\
\hline
\end{tabular}

Pembuatan basis gel dilakukan dengan cara sebanyak $5 \mathrm{~g}$ Na-CMC dicampur dengan $10 \mathrm{~g}$ gliserin, $5 \mathrm{~g}$ propilenglikol dan dicukupkan 100 $\mathrm{g}$ dengan aquades lalu dipanaskan pada suhu $50^{\circ} \mathrm{C}$ dan diaduk hingga homogen. Pembuatan basis gel ini berfungsi sebagai media pembawa untuk ekstrak etanol daun bermuda.

Basis gel yang akan dibuat dalam penelitian ini memiliki Konsentrasi ekstrak daun rumput Bermuda yang berbeda-beda, yaitu $1 \%, 3 \%$ dan $5 \%$ sebanyak 25 gram.

Tabel 2. formulasi gel ekstrak daun rumput Bermuda.

\begin{tabular}{ccccc}
\hline \multirow{2}{*}{ No } & \multirow{2}{*}{ Bahan } & \multicolumn{3}{c}{ Komposisi (g) } \\
\cline { 3 - 5 } & F1 & F2 & F3 \\
\hline \multirow{2}{*}{1} & $\begin{array}{c}\text { Ekstrak daun } \\
\text { bermuda }\end{array}$ & $0,25 \mathrm{~g}$ & $0,75 \mathrm{~g}$ & $1,25 \mathrm{~g}$ \\
\hline 2 & Na-CMC & $1,25 \mathrm{~g}$ & $1,25 \mathrm{~g}$ & $1,25 \mathrm{~g}$ \\
\hline 3 & Gliserin & $2,5 \mathrm{~g}$ & $2,5 \mathrm{~g}$ & $2,5 \mathrm{~g}$ \\
\hline 4 & Propilenglikol & $1,25 \mathrm{~g}$ & $1,25 \mathrm{~g}$ & $1,25 \mathrm{~g}$ \\
\hline 5 & Aquades ad & $25 \mathrm{~g}$ & $25 \mathrm{~g}$ & $25 \mathrm{~g}$ \\
\hline
\end{tabular}




\section{Pengujian efektivitas terhadap luka bakar}

Sebelum pengujian pengaruh pemberian topikal ekstrak daun rumput bermuda, hewan coba yang digunakan adalah kelinci (Oryctolagus cuniculus) yang sehat, dengan berat badan 1,5$2,0 \mathrm{~kg}$. Diaklimatisasi dengan lingkungan kandang selama 7 hari bertujuan agar hewan uji terbiasa dengan lingkungannya, terlebih dahulu bulu kelinci dicukur pada bagian punggungnya. Kemudian kelinci dianastesi total terlebih dahulu dengan ketamin 1-2 mg/kg BB secara intravena pada telinga kelinci. Kemudian dilanjutkan dengan mengatur suhu $60^{\circ} \mathrm{C}$ selama 20 detik, kemudian diinduksi dengan ditempelkan pada bagian punggung kelinci berdiameter $20 \mathrm{~mm}$. Selanjutnya Luka yang terjadi diukur, setelah itu diolesi bahan uji sebanyak $200 \mathrm{mg}$ sesuai kelompok masing-masing, pengamatan dilakukan secara visual dengan memperhatikan perubahan diameter luka selama 21 hari.

Tabel 3. Pembagian Kelompok Perlakuan Uji

\begin{tabular}{cl}
\hline $\begin{array}{c}\text { Nama } \\
\text { Kelompok }\end{array}$ & \multicolumn{1}{c}{ Perlakuan } \\
\hline Kelompok:1 & $\begin{array}{l}\text { kelompok kontrol negatif, luka } \\
\text { bakar dioleskan basis gel Na CMC } \\
\text { Luka bakar dioleskan gel ekstrak } \\
\text { Kelompok:2 } \\
\text { daun rumput Bermuda 1\% }\end{array}$ \\
Kelompok:3 & $\begin{array}{l}\text { Luka bakar dioleskan gel ekstrak } \\
\text { daun rumput Bermuda 3\% }\end{array}$ \\
Kelompok:4 & $\begin{array}{l}\text { Luka bakar dioleskan gel ekstrak } \\
\text { daun rumput Bermuda 5\% }\end{array}$ \\
Kelompok:5 & $\begin{array}{l}\text { Kelompok kontrol positif, luka } \\
\text { bakar dioleskan bioplacenton }\end{array}$ \\
\hline
\end{tabular}

\section{Variabel Analisis Data}

pengukuran diameter luka bakar menggunakan rumus sebagai berikut:

$$
d x=\frac{d 1+d 2+d 3+d 4}{4}
$$

Keterangan:

$\mathrm{dx}$ (Diameter luka hari ke $\mathrm{x}), \mathrm{d}_{1}$ (Diameter 1), $\mathrm{d}_{2}$ (Diameter 2), $\mathrm{d}_{3}$ (Diameter 3), $\mathrm{d}_{4}$ (diameter 4).

Untuk rata-rata diameter luka bakar (mm) penyembuhan luka bakar dihitung dengan rumus.

Keterangan:

$$
\mathrm{P} \%=\frac{d 0-d x}{d 0} \times 100 \%
$$

P\% :Untuk persentase penyembuhan luka

$\mathrm{d}_{\mathrm{o}} \quad$ : Untuk diameter luka bakar

$\mathrm{d}_{\mathrm{x}} \quad$ : Untuk diameter luka pada hari tertentu (Gupta, 2016).

kemudian dianalisis secara statistik anova dengan uji one-way anova yang dilanjutkan dengan uji post hoc Duncan pada taraf kepercayaan $95 \%$.

\section{HASIL DAN PEMBAHASAN}

\section{Hasil Pembuatan Eksrak Etanol}

Hasil dari proses maserasi simplisia daun rumput bermuda dengan bobot 437,10 g menggunakan pelarut etanol 96\%, diperoleh hasil ekstrak kental sebanyak 175,86 g dengan hasil rendemen sebesar $40,23 \%$.

\section{Hasil Uji Fitokimia}

Ekstrak etanol daun rumput bermuda positif mengandung senyawa bioaktif yang berperan dalam memberikan khasiat atau efek biologi, antara lain flavonoid, saponin, fenolik, alkaloid dan tannin.

Tabel 4. Hasil Penapisan Fitokimia Ekstrak Daun Rumput Bermuda

\begin{tabular}{cllc}
\hline No & $\begin{array}{c}\text { Komponen } \\
\text { Senyawa }\end{array}$ & $\begin{array}{c}\text { Hasil } \\
\text { Identifikasi }\end{array}$ & Ket \\
\hline 1 & Flavonoid & Orange & + \\
2 & Saponin & Buih & + \\
3 & Alkaloid & Endapan & + \\
4 & Tannin & Hijau gelap & + \\
5 & Fenolik & Hijau tua & + \\
\hline
\end{tabular}

Hasil Pengujian Pengaruh Pemberian Topikal Ekstrak Daun Rumput Bermuda Terhadap Penyembuhan Luka Bakar

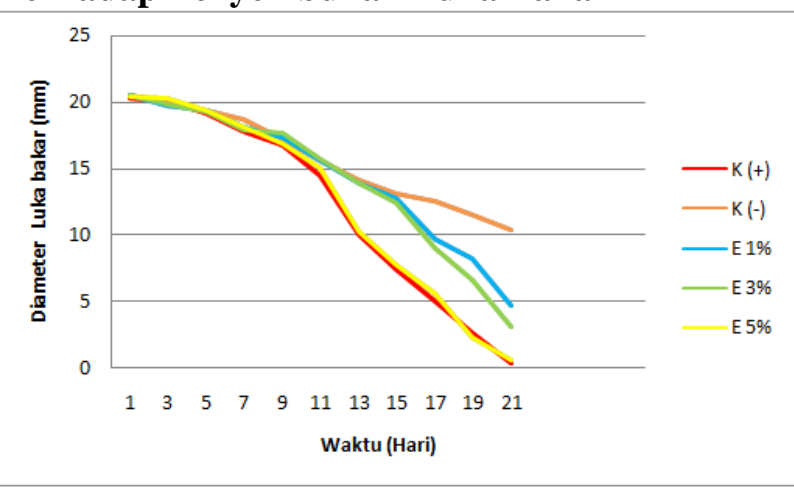

Gambar 1. Grafik penyembuhan luka bakar Keterangan:
$\mathrm{K}(+) \quad=\quad$ Kontrol Positif
$\mathrm{K}(-) \quad=$ Kontrol Negatif
$\mathrm{E} 1 \%=$ Ekstrak daun rumput bermuda konsentrasi $1 \%$
E 3\% = Ekstrak daun rumput bermuda konsentrasi3\%
E 5\% = Ekstrak daun rumput bermuda konsentrasi 5\% 


\section{PEMBAHASAN}

Penelitian ini merupakan penelitian eksperimental yang bertujuan untuk mengetahui aktivitas ekstrak etanol daun rumput bermuda Cynodon dactylon L. Pers terhadap penyembuhan luka bakar pada kelinci jantan yang telah diinduksi dengan logam panas berupa solder. Penelitian ini dilakukan identifikasi tanaman untuk memastikan bahwa tanaman yang digunakan adalah benar daun rumput bermuda. Identifikasi dilakukan di UPT. Sumber daya hayati Sulawesi, Universitas Tadulako. Hasil identifikasi menyatakan bahwa tanaman yang digunakan dalam penelitan ini adalah benar daun rumput bermuda dengan bahasa latin Cynodon dactylon $\mathrm{L}$.

Metode maserasi dipilih karena merupakan cara paling tepat untuk simplisia dengan tekstur yang lunak seperti yang digunakan dalam penelitian ini dan memungkinkan cairan penyari berpenetrasi ke dalam rongga sel sehingga akan melarutkan zat aktif, karena adanya perbedaan konsentrasi maka zat aktif akan berdifusi ke luar melalui dinding sel. Cairan penyari yang digunakan pada proses meserasi ini adalah etanol 96\%, karena bersifat universal yang mampu menarik semua jenis zat aktif, baik bersifat polar, semipolar, dan non polar, serta toksisitasnya rendah (Dirjen POM, 1986).

Dalam penelitian ini digunakan beberapa variasi konsentrasi ekstrak dengan menggunakan basis gel. Basis gel dibuat dengan menggunakan sodium karboksimetil selulosa (Na-CMC) dengan penambahan propilenglikol sebagai kosolven dan gliserin sebagai emolient (Rowe, 2009 ). Kemudian dilakukan pembuatan variasi konsentrasi ekstrak 1\% yang mengandung bahan aktif ekstrak rumput bermuda sebanyak $0,25 \mathrm{~g}, 3 \%$ mengandung bahan aktif ekstrak rumput bermuda $0,75 \mathrm{~g}$ dan $5 \%$ mengandung bahan aktif ekstrak rumput bermuda $1,25 \mathrm{~g}$.

Dalam pengujian aktivitasnya, pemberian topikal ekstrak daun rumput bermuda terhadap penyembuhan luka bakar pada 5 ekor hewan uji kelinci yang telah diaklimatisasi selama 7 hari dengan tujuan hewan uji dapat beradaptasi dengan lingkungan barunya. Luka bakar diinduksi pada bagian punggung kelinci yang sebelumnya telah dicukur sebanyak 5 bagian luka bakar yang mewakili 5 kelompok dosis pada tiap ekor kelinci dengan menggunakan solder berupa logam panas yang telah dimodifikasi, dimana luka yang terbentuk berupa lingkaran dengan diameter sekitar 20 $\mathrm{mm}$. Sebelum diinduksi luka bakar, kelinci dianastesi terlebih dahulu menggunakan injeksi ketamin secara intravena. Adapun Induksi luka bakar yang telah dilakukan mengakibatkan terjadinya kerusakan pada bagian epidermis dan sebagian dermis dengan ciri kulit mengalami pelepuhan, kulit kering dan dasar luka berwarna merah pucat (Moenadjat, 2003).

Hasil pengamatan luka bakar tersebut dapat dikatakan bahwa hewan uji mengalami luka bakar derajat II. Selanjutnya luka bakar tersebut masing-masing diberikan perlakuan yaitu dengan basis gel tanpa esktrak sebagai kontrol negatif, kemudian basis gel dengan masing-masing konsentrasi ekstrak 1\%, 3\%, 5\% serta gel bioplacenton sebagai kontrol positif. Pemberian perlakuan dilakukan selama 21 hari dengan interval pengolesan 1 kali sehari $200 \mathrm{mg}$. Adapun pengamatan penyembuhan luka bakar yang dilakukan pada kelinci menunjukkan adanya perubahan, yang di mana luka tertutupi dahulu pada bagian atasnya oleh darah yang membeku yang membentuk lapisan kerak atau scab.

Analisis data selanjutnya akan dilakukan dengan menggunakan metode uji One Way Anova untuk mengetahui ada tidaknya perbedaan yang signifikan antar kelompok. Hasil dari analisis menunjukkan adanya perbedaan antar kelompok dengan nilai yang signifikan ( $p<$ 0,05). Di mana pada analisis tersebut menunjukkan bahwa adanya efek terhadap penyembuhan luka bakar yang berbeda secara signifikan.

Hasil uji Post hoc Duncan menunjukkan efek penyembuhan luka bakar kontrol negatif berbeda signifikan dengan perlakuan basis gel ekstrak daun rumput bermuda $1 \%$ dan 3\%, konsentrasi ekstrak $1 \%$ dan $3 \%$ memiliki perbedaan yang tidak signifikan, namun berbeda signifikan dengan konsentrasi ekstrak 5\% dan kontrol positif, antara konsentrasi ekstrak 5\% dan kontrol positif memiliki perbedaan yang tidak signifikan. Kontrol positif memiliki efektivitas penyembuhan luka bakar yang lebih baik dibandingkan dengan basis gel yang mengandung ekstrak daun rumput bermuda. sel.

Ekstrak daun rumput bermuda dengan semua variasi konsentrasi yaitu 1\%, 3\%, dan 5\% memberikan efek penyembuhan luka bakar karena adanya terkandung senyawa aktif yang dapat mempercepat proses penyembuhan. Senyawa tersebut antara lain flavonoid, saponin, dan tannin. Hal ini telah sesuai dengan penelitian 
Aisah, P I utami, (2018) bahwa senyawa flavonoid, saponin, dan tannin mempunyai efek penyembuhan luka.

\section{KESIMPULAN}

Berdasarkan penelitian yang telah dilakukan mengenai pengujian efektivitas ekstrak etanol daun rumput bermuda (Cynodon dactylon L. Pers.) terhadap penyembuhan luka bakar pada kelinci (Oryctolagus cuniculus) jantan, dapat disimpulkan sebagai berikut: Ekstrak daun rumput bermuda (Cynodon dactylon L. Pers.) memiliki aktivitas dalam penyembuhan luka bakar pada punggung kelinci (Oryctolagus cuniculus) dan Ekstrak daun rumput bermuda (Cynodon dactylon L. Pers.) dengan konsentrasi 5\% efektif terhadap penyembuhan luka bakar pada punggung kelinci (Oryctolagus cuniculus).

\section{SARAN}

Perlu dilakukan penelitian lebih lanjut untuk mengetahui apakah ekstrak daun rumput bermuda memiliki efek penyembuhan sebagai antibakteri pada luka yang terinfeksi.

\section{DAFTAR PUSTAKA}

Aisah, P I Utami and E Genatrika, 2018, The Effectiveness of Ointment of Patah Tulang Stem's (Euphorbia Tirucalli) Ethanol Extract for Burn Wound Healing on White Rats (Rattus Norvegicus). Faculty of Pharmacy Universitas Muhammadiyah Purwokerto

Dirjen POM Depkes RI, (1986), Sediaan Galenik, Departemen Kesehatan RI, Jakarta.
Grace PA, Borley NR, Safitri A. 2006. At a glance ilmu bedah. Edisi ke-3. Jakarta: Erlangga.

Gupta VK, Pathak SS, Jain MK. Evaluation of burn wound healing property of ocimun sanctum by monitoring of reepithelization in rabbits. Int. basic clin pharmacol. 2016: 5: 146-148.

Jailani, M. (2005). SYSTEMIC INFLAMMATORY RESPONSE SYNDROME (SffiS) PADA LUKA BAKAR. Jurnal Kedokteran Syiah Kuala, 5(1), 27-39.

Kaliyaperumal, A., Kumarakurubaran, S., and Saradha D, M. (2013). Cynodon dactylon (L.) Pers.: An updated review of its phytochemistry and pharmacology. Journal of Medicinal Plants Research, Vol. 7, 3477-3478.

Mappa, T., H.J., E. and K.N., 2013, Formulasi Gel Ekstrak Daun Sasaladahan (Peperomia pellucid L.) dan Uji Efektivitasnya Terhadap Luka Bakar pada Kelinci (Oryctolagus cuniculus), Jurnal Ilmiah Farmasi, 2(2), pp.49-56.

Martin, L., Y., dan Alexander, G., 2017, Bioengineering In Wound Healing A System Approach, World Scientific Publishing, London.

Moenadjat, Yefta. (2003). Luka Bakar dan Tatalaksana Edisi ke 4. Jakarta: FKUI.

Rowe, R.C. et Al. (2009). Handbook of Pharmaceutical Excipients, 6 th Ed, The Pharmaceutical Press, London. 